\title{
Intelligent Kinetic Façade System for Controlling Spatial Comfort towards Hanok
}

\author{
[ Tae-Ryong Kim and Seung-Hoon Han ]
}

\begin{abstract}
The purpose of this study is to suggest a kinetic façade and their controlling system towards Hanok. For this study, Hanok's degree of integrative comfort was analyzed and environment assessment system of Hanok comfort was utilized. Using the assessment system, the controlling system of kinetic façade was proposed and verified its applicability. As a result, it is turned that the proposed system would have a pretty good applicability to the relevant practical field.
\end{abstract}

Keywords- Intelligent Comfort Evaluation, Hanok Performance, Integrated Comfort, Indoor Environment, Kinetic Façade.

\section{Introduction}

Recently, there are huge demand of Hanok in Korean residential market. As their lifestyle has changed, the Korean traditional residential building called Hanok is not suitable for modern life. So there has been a huge movement in the field of market and research. Many trials for styling new Hanok were attempted and relevant researches have been performed. In this circumstance, Neo-Hanok shows up. Neo-Hanok has the beauty of traditional Hanok and modernized space composition reasonably.

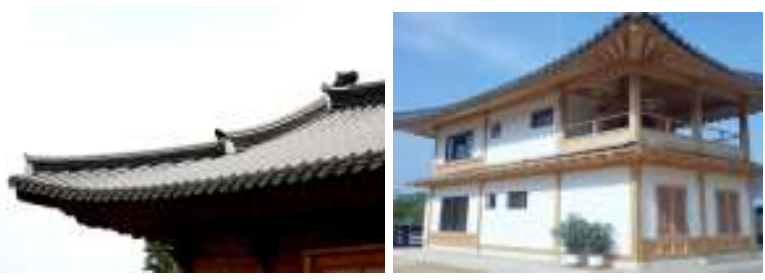

Figure 1. Diffference eaves depth of traditional Hanok(Left) and NeoHanok(Right)

But there are something missed in Neo-Hanok; traditional Hanok has normally long depth of eaves but NeoHanok has various typed of eaves as shown on Figure 1. This change can affect Hanok's performance siginificantly.

For example, in traditional Hanok, long eaves act like a horizontal louver that prevents direct radiation in the Summer season. Therefore, additional façade system would be needed to guarantee the same performance towards NeoHanok. The ultimate goal of this study is to suggest an kinetic façade system for Hanok having short eaves and its controlling system.

Tae-Ryong Kim and Seung-Hoon Han*

School of Architecture, Chonnam National University, Korea

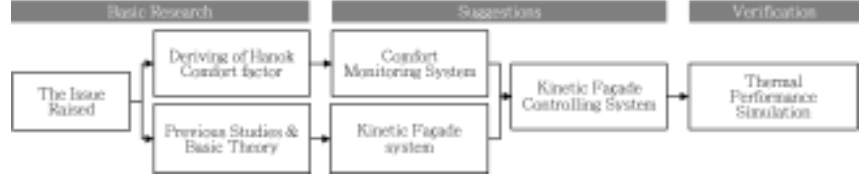

Figure 2. Research flowchart

To build the control system for the proposed kinetic façade, the previous study of indoor comfort performance evaluation system ${ }^{1}$ was investigated. Through the step shown on Figure 2, this study suggests a kinetic façade and its controlling system finally.

\section{Integrated Environmental Monitoring System for Hanok}

\section{A. Deriving Hanok Comfort Factors}

The purpose of this session is to investigate an assessment system of the various factors for environmental comfort performance such as individual characteristics, life style, social elements, and so on.

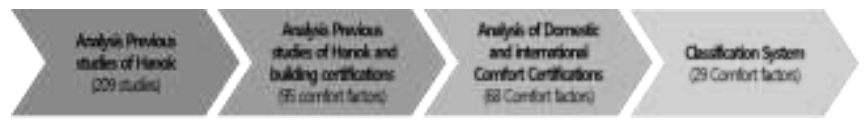

Figure 3. Comfort factor deriving process

For this study, comfort factors of Hanok residence were derived. To induce comfort factors of Hanok residence, four steps of analysis have been performed. Each step shown in Figure 3. One hundred forty two previous studies on indoor comfort, sixty four previous studies on Hanok and fifteen certifications of residence have been analyzed through the steps.

The integrated comfort index of Hanok is composed of twenty nine comfort factors and those can be classified into two parts for convenience of assessment. The first one is psychology cognitive factors based on residents' experiences such as convenience of building and beauty of building. Assessment time for these factors is pre-occupancy of building. The second one is physical perception factors based on physical environment of building such as humidity, heat insulation property, air tightness and so on. The factors in physical perception factor can be analyzed before occupancy of building. In the final step of the study, these two categorized factors can be assessed comprehensively.

${ }^{1}$ T. Kim, K. Kim. and S. Han, "Implementation of Intelligent PreOccupancy Evaluation for Hanok Performance," Proceedings of AABES 2015, 2015. 
Proc. of The Second Intl. Conf. On Advances In Economics, Social Science and Human Behaviour Study - ESSHBS 2015 Copyright (C) Institute of Research Engineers and Doctors, USA .All rights reserved.

ISBN: 978-1-63248-076-7 doi: 10.15224/ 978-1-63248-076-7-60

\section{B. Measuring Hanok Comfort Factors}

There are twenty nine integrated comfort factors of Hanok as described in Figure 5. In physical perception factors, some factors can be measured by sensor and the other factors may not. Table I shows the measurement methods of physical perception factors, while physiological cognition factors can be measured by surveys.

TABle I. MEASUREMENT METHOd OF PHySICAL PERCEPTION FACTOR

\begin{tabular}{|c|c|c|}
\hline Factor & Definition & Measuring Method \\
\hline $\begin{array}{l}\text { Humidity } \\
\text { Control }\end{array}$ & $\begin{array}{l}\text { Humidity control } \\
\text { performance of material } \\
\text { and equipment }\end{array}$ & $\begin{array}{c}\text { Sensor } \\
\text { (Relative h Humidity) }\end{array}$ \\
\hline $\begin{array}{c}\text { Heat } \\
\text { Insulation } \\
\text { Property }\end{array}$ & $\begin{array}{l}\text { Heat exchange } \\
\text { performance of wall, } \\
\text { slab and roof system }\end{array}$ & $\begin{array}{c}\text { Plan analysis \& Infrared } \\
\text { camera }\end{array}$ \\
\hline $\begin{array}{c}\text { Air } \\
\text { Tightness }\end{array}$ & Resistance of air leakage & $\begin{array}{c}\text { Tightness test } \\
\text { (Leakage rate per unit area) }\end{array}$ \\
\hline $\begin{array}{c}\text { Solar } \\
\text { radiation }\end{array}$ & $\begin{array}{l}\text { Indoor solar energy gain } \\
\text { or shielding }\end{array}$ & $\begin{array}{l}\text { Sensor monitoring } \\
\text { (wh) }\end{array}$ \\
\hline $\begin{array}{c}\text { Sound } \\
\text { Absorption }\end{array}$ & $\begin{array}{l}\text { Sound absorption } \\
\text { performance of interior } \\
\text { material }\end{array}$ & $\begin{array}{l}\text { Sound absorption test } \\
\text { (check the indoor dB from } \\
\text { indoor sound source) }\end{array}$ \\
\hline $\begin{array}{l}\text { Sound } \\
\text { Insulation }\end{array}$ & $\begin{array}{l}\text { Sound insulation } \\
\text { performance from } \\
\text { outside sound }\end{array}$ & $\begin{array}{l}\text { Sound insulation Test } \\
\text { (check the indoor dB from } \\
\text { outdoor sound source) }\end{array}$ \\
\hline $\begin{array}{l}\text { Natural } \\
\text { lighting }\end{array}$ & $\begin{array}{c}\text { Natural lighting } \\
\text { performance }\end{array}$ & $\begin{array}{c}\text { Sensor monitoring } \\
\text { (Lux) }\end{array}$ \\
\hline $\begin{array}{l}\text { Artificial } \\
\text { lighting }\end{array}$ & $\begin{array}{l}\text { Artificial lighting } \\
\text { performance }\end{array}$ & $\begin{array}{l}\text { Sensor monitoring } \\
\text { (Lux) }\end{array}$ \\
\hline $\begin{array}{l}\text { Cleanliness } \\
\text { of air }\end{array}$ & $\begin{array}{l}\text { Dust, } \mathrm{CO} \text { and } \mathrm{CO}_{2} \text { 's } \\
\text { ratio of indoor air }\end{array}$ & $\begin{array}{c}\text { Sensor } \\
\text { (the ratio of the air) }\end{array}$ \\
\hline $\begin{array}{l}\text { Deodorizati } \\
\text { on }\end{array}$ & $\begin{array}{l}\text { Deodorization } \\
\text { performance of material } \\
\text { and equipment }\end{array}$ & $\begin{array}{c}\text { Plan analysis } \\
\text { (material and equipment's } \\
\text { deodorization performance) }\end{array}$ \\
\hline Ventilation & $\begin{array}{c}\text { Ventilation performance } \\
\text { of material and } \\
\text { equipment }\end{array}$ & $\begin{array}{c}\text { Ventilation test } \\
\text { (Ventilation hour per unit) }\end{array}$ \\
\hline $\begin{array}{l}\text { Maintainabi } \\
\text { lity }\end{array}$ & $\begin{array}{l}\text { Maintainability comes } \\
\text { from structure and } \\
\text { material of building }\end{array}$ & $\begin{array}{c}\text { Plan analysis } \\
\text { (Structure and material } \\
\text { check) }\end{array}$ \\
\hline Security & $\begin{array}{l}\text { Security comes from } \\
\text { design and equipment of } \\
\text { building }\end{array}$ & $\begin{array}{c}\text { Plan analysis } \\
\text { (Design and equipment } \\
\text { check) }\end{array}$ \\
\hline Harmless & $\begin{array}{l}\text { Harmless comes from } \\
\text { eco-friendly material }\end{array}$ & $\begin{array}{c}\text { Plan analysis } \\
\text { (Material check) }\end{array}$ \\
\hline
\end{tabular}

\section{Suggestion of Integrated Environment Monitoring System}

In the above 14 factors, some of factors can be measured by a single test, but the other factors cannot. Because the weather and solar position gives the effect to the values of factor. So some of factor that effected by weather and solar are needed monitoring system to measure the values.

Figure 4 indicates the sensors to be utilized. Each sensor measuring one of factors sends the database server the collected information through a relay node too. This relay node doesn't have a function for gathering information, but is capable of measuring output information in the TCP/IP and/or UART channels similar to the above PMV case. All sensor nodes are assembled in a set of the single module for the convenience of installation and management in purpose. A relay node included in the module synthesizes information from all different sensors and sends the information to database server.

Indoor temperature, relative humidity, air flow rate sensors and relay node that can transfer information to analyzable data are became a module placed in each room for collecting indoor-generated data. Other sensors became another module that each sensor was modularized by collected data type. Modularized sensors are also placed in the rooms.

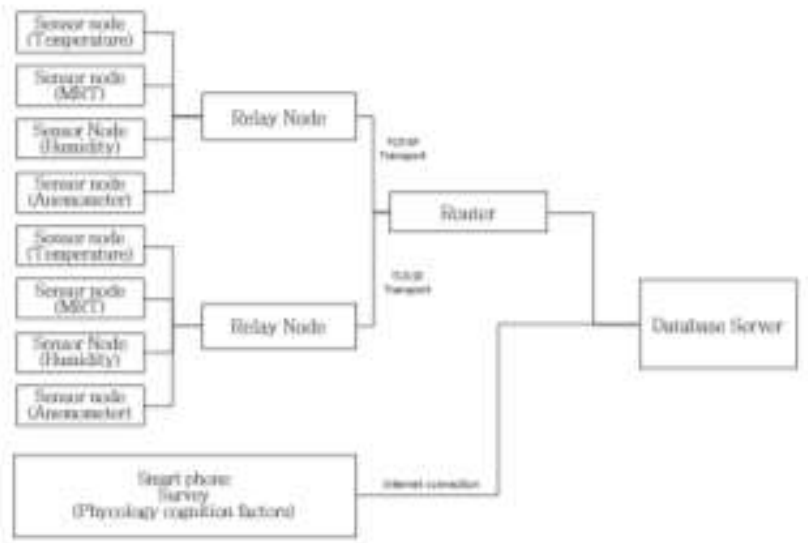

Figure 4. Integrated Environment Monitoring System for Hanok

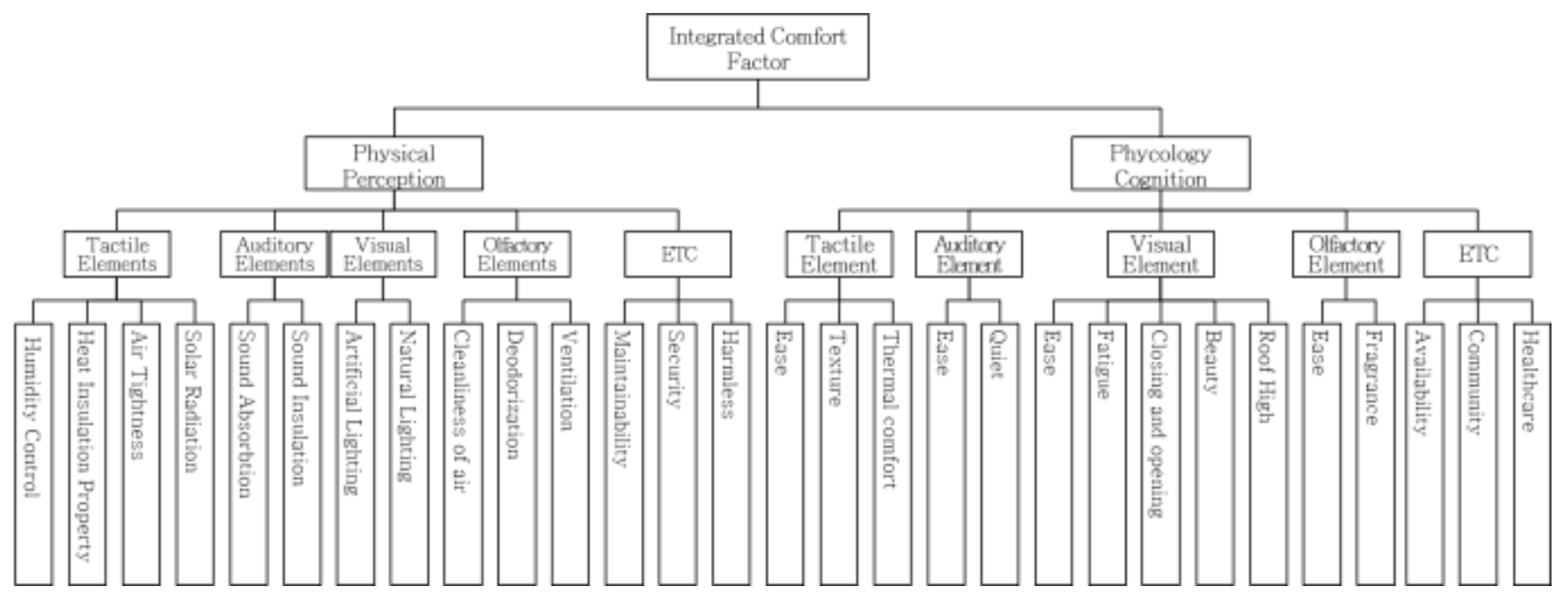

Figure 5. Integrated Comfort Factors 


\section{Kinetic Façade System towards Hanok}

\section{A. Basic Theories for the Shading}

Shading system is an element for controlling the solar radiation to adjust an indoor environment. This component is normally fixed on the wall and unable to control the solar radiation effectively. In addition, a fixed vertical louver interferes for the outside views. So, a type of moveable louver seems available to be activated for the building façade in order to resolve mentioned problems.

On the other hand, a light shelf is an architectural element which allows the daylight to penetrate into the indoor space as deep as possible and blocks the direct sunlight to prevent a glare. This type of the shading system has been proven to decrease the artificial lighting consumption quite much. Thus, it improves the visual comfort to occupants, and may reduce cooling loads by blocking the direct sunlight.
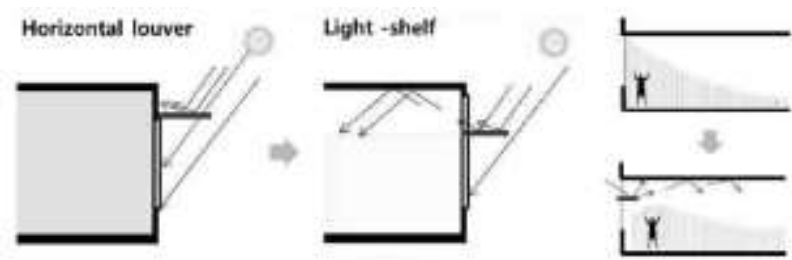

Figure 6. Comparison of Horizontal Louver and Light Shelf

As an advanced type of shading system, kinetic façade system is an active control system for making better indoor environmental condition by changing its function according to the exterior surroundings. This system is designed to move partial components for responding to environmental changes outside. Recently, practical implementations of the kinetic system are being realized with advanced technologies in mechanics, electronics and robotics, while those still have considerable problems in aspects of production and maintenance costs, because they require tight collaborations among various fields.

\section{B. Design Process of the Proposed Kinetic Façade System}

This study proposes a kinetic façade of the modular system applied with integrative functions of vertical louver and light shelf. The suggested system can change the functions by the position of the sun. This unique combination has the distinction from the existing kinetic façade systems.
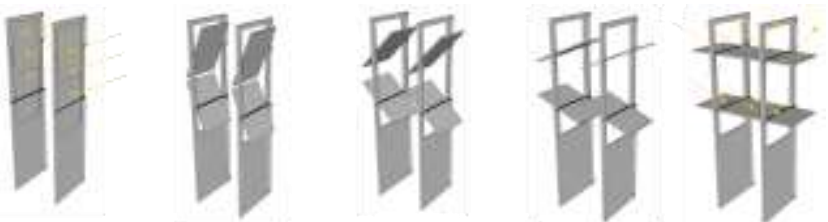

Figure 7. Transformation Procedure of the Proposed Façade System
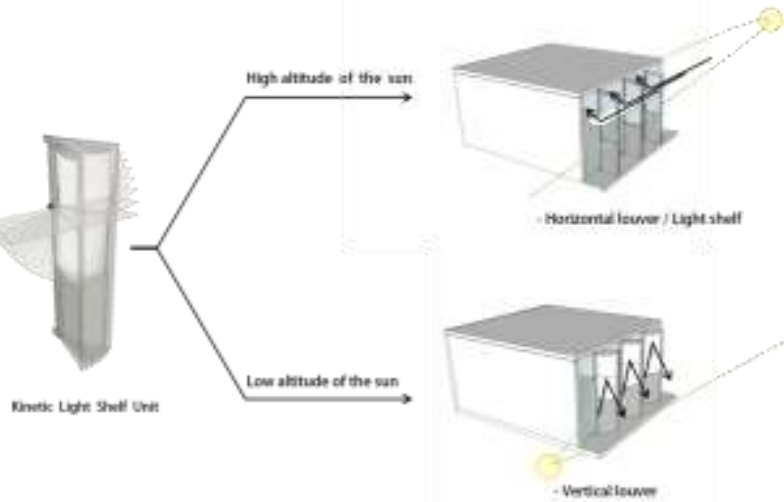

Figure 8. Funtion Changes According to the Altitude of the Sun

Two comparative functions such as penetrating natural daylight and blocking the solar radiation are embodied and optimized into the system, and the proposed mechanism has provided to support relatively enhanced environmental controls.

\section{Composition of the Control System for the Kinetic Façade}

\section{A. Suggestion of Intelligent Control System for Kinetic Façade system.}

In this session, an integrated environmental monitoring system towards Hanok is to be suggested. If the proposed kinetic façade system comes together as shown on Figure 7, this system can bring greater comfort performance to resident.

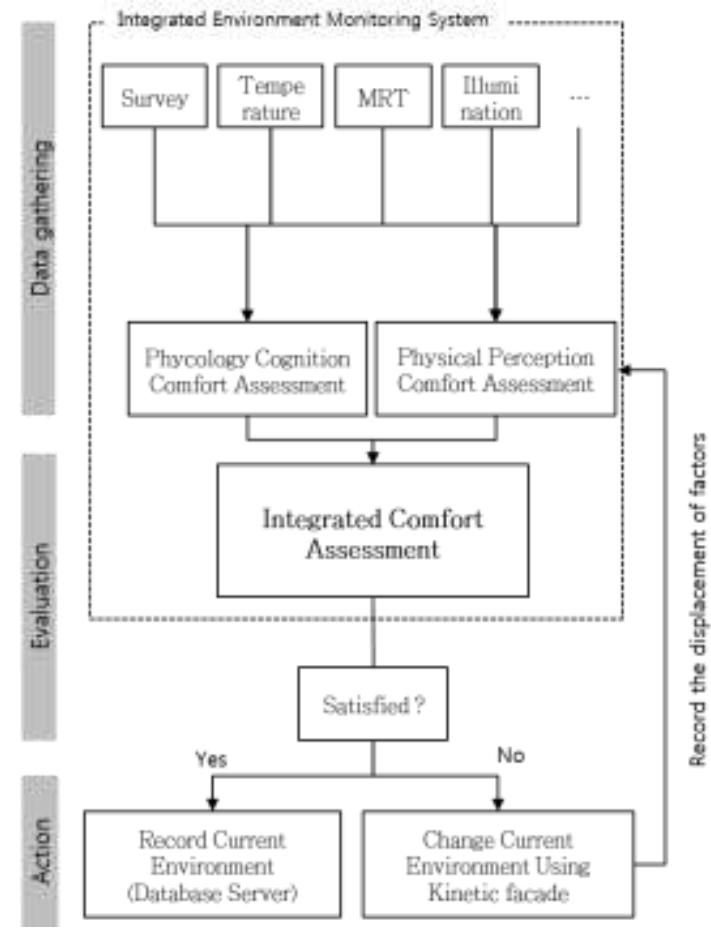

Figure 9. Application of Intelligent Control System 
Proc. of The Second Intl. Conf. On Advances In Economics, Social Science and Human Behaviour Study - ESSHBS 2015 Copyright (c) Institute of Research Engineers and Doctors, USA .All rights reserved.

ISBN: 978-1-63248-076-7 doi: 10.15224/ 978-1-63248-076-7-60

Established equipment control system is based on fixed values such as recommended indoor temperature, humidity and so on. Otherwise, this system can evaluate current indoor environment based on resident's individual situation. With recording the displacement of factors and satisfied indoor environment, this equipment control systems could be more accurate year by year. The below example shows a kinetic façade system for Hanok.

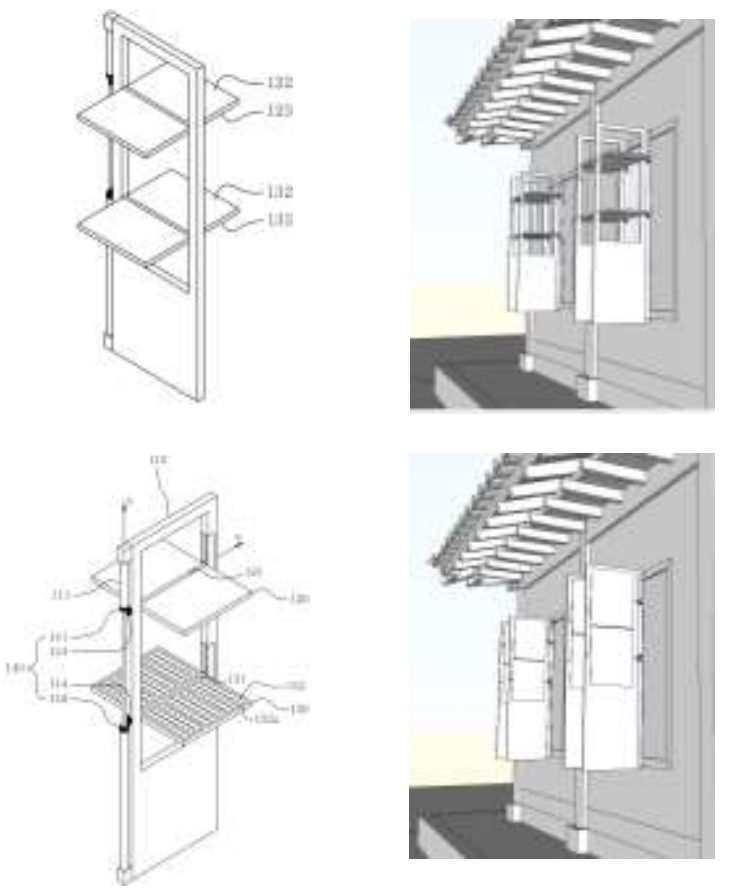

Figure 10. Kinetic Façade System for Hanok

TABLE II. OUtLINES OF SimULATION SETTINGS

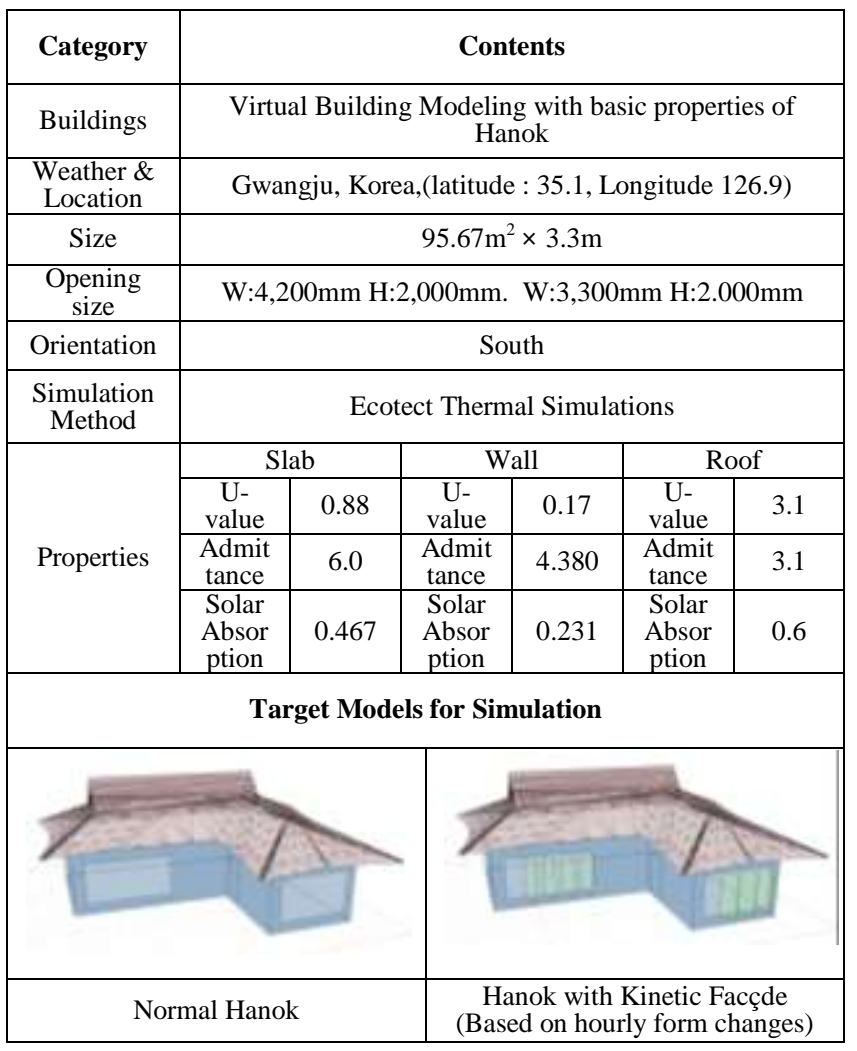

\section{B. Thermal performance of the proposed kinetic façade system}

The proposed façade system is assumed to respond to human and environment interactively, and this can be very useful to residents. The energy analysis should be followed in this sense to popularize and commercialize its functionality. Ecotect Analysis by Autodesk was used as an energy analysis tool and Table II shows the outlines of the analysis from energy simulations. As a result, 7\% reduction in aspects of energy consumption per year was concluded from the simulations.

TABLE III. HEATING AND COOLING LOAD

\begin{tabular}{|c|c|c|c|c|c|c|}
\hline \multirow[b]{2}{*}{ Type } & \multicolumn{6}{|c|}{ Monthly Load (wh) } \\
\hline & Month & $\begin{array}{c}\text { Heating } \\
\text { Load } \\
\text { (Wh) }\end{array}$ & $\begin{array}{c}\text { Cooling } \\
\text { Load } \\
\text { (Wh) }\end{array}$ & Month & $\begin{array}{c}\text { Heating } \\
\text { Load } \\
\text { (Wh) }\end{array}$ & $\begin{array}{c}\text { Cooling } \\
\text { Load } \\
\text { (Wh) }\end{array}$ \\
\hline \multirow{7}{*}{$\begin{array}{c}\text { Normal } \\
\text { Hanok }\end{array}$} & Jan & 2098607 & 0 & Jul & 0 & 478761 \\
\hline & Feb & 1557296 & 0 & Aug & 0 & 553445 \\
\hline & Mar & 1080548 & 0 & Sep & 0 & 254341 \\
\hline & Apr & 474113 & 0 & Oct & 205682 & \\
\hline & May & 113224 & 0 & Nov & 819730 & \\
\hline & Jun & 0 & 109165 & Dec & 1664385 & \\
\hline & SUM & \multicolumn{5}{|c|}{9409297} \\
\hline \multirow{7}{*}{$\begin{array}{c}\text { Hanok } \\
\text { with } \\
\text { Kinetic } \\
\text { Façade }\end{array}$} & Jan & 2008397 & 0 & Jul & 0 & 381216 \\
\hline & Feb & 1492033 & 0 & Aug & 0 & 456266 \\
\hline & Mar & 1031442 & 0 & Sep & 0 & 167360 \\
\hline & Apr & 452661 & 0 & Oct & 215007 & 0 \\
\hline & May & 128522 & 0 & Nov & 775230 & 0 \\
\hline & Jun & 1828 & 26752 & Dec & 1590676 & 0 \\
\hline & SUM & \multicolumn{5}{|c|}{8727390} \\
\hline
\end{tabular}

\section{v. Conclusion}

The purpose of this study is to suggest an intelligent kinetic façade system for Hanok and/or Neo-Hanok. To suggest this system, twenty nine comfort factors were derived and analyzed by an integrated environmental monitoring system presented. Proposed monitoring system can measure comfort factors by sensors and automatically send them to the database server to analyze situations easily.

Through the final step of this study, composition of the proposed kinetic façade system and its control system were suggested and experimentally verified for the adaptability of its energy performance by a thermal energy analysis tool. The simulation result shows 681,907 (wh) energy savings and this is equivalent to $7 \%$ of the total energy consumption of the normal Hanok.

In conclusion, this study has suggested an ideal kinetic façade system and their controlling methods. But there are still some issues to be resolved; the proposed kinetic façade system was simulated in limited range and the simulation contained only hourly movements of the façade system. So, some factors may be missed such as human reactions etc. due to technical limitations of the simulation tool. In this sense, an additional simulation for human behaviors is under 
active research and relevant analyses should be an ongoing theme for further researches.

\section{Acknowledgment}

This research was supported by a grant (14AUDPB070933-02) from Urban Architecture Research Program (Development of Hanok Technology, Phase II) funded by Ministry of Land and Transport Affairs of Korean Government.

\section{References}

[1] S. Han, O. Im, M. Lee and D. Cheon, June, 2013, "A Study on the Establishment of an Evaluation System for Integrative Comfort Performance of Korean Traditional Residence," Journal of the Korean Housing Association, vol. 24, no.3, pp. 27-35.

[2] G. Cho, 2003, "Decision-Making by Analytic Hierarchy Process for Leaders," Euijeongbu, Donghyun Publication Co., 2003.

[3] S. Cho and N. Kang, 2011, "A Study on the Evaluation Indicators of Healthy Housing Quality of Multi-Family Housing," Journal of Korean Housing Association, vol. 22, no. 1, pp.43-55.

[4] S. Jung and J. Seo, March, 2012, "A Study on the Visual Characteristics of New Material for Emotional Housing Space Design," Journal of Korean Housing Association, vol. 23, no. 3, pp. 71-78.

[5] Y. Kwon, 2010, "A Consumer Research for NEO-Hanok Maeul, Korean Traditional Style Village," Journal of Architectural Institute of Korea, vol. 26, no. 11, pp. 97-106.

[6] Y. Kwon, W. Um and H. Kim, 2011, "A Design Guidelines for NEOHanok Maeul, Korean Traditional Style Village," Journal of Architectural Institute of Korea, vol. 27, no. 3, pp. 39-50.

[7] S. Min, K. Byun and T. Kim, 2012, "A Study on the Attractive Items of Hanok in Urban Area - Focused on Preceding Studies," Proceedings of Architectural Institute of Korea, vol. 32(1), pp. 91-92.

[8] S. Min and T. Kim, September, 2012, A Study on the Attractive Items of Hanok in Urban Area focused on Preceding Studies, Journal of Korean Institute of Rural Architecture, vol. 14, no. 3, pp. 61-68.

[9] S. Kim, Y. Chang, J. Kang and S. Han, 2013, "Implementation of the Wireless Smart Sensor Network for Spatial Comfort Performance of Hanok Residence," Proceeding of the 7th International Conference on Anti-counterfeiting, Security, and Identification (ASID 2013), pp. 4447.

[10] T. Kim, K. Kim, S. Kim and S. Han, 2014, "A Composition of Monitoring System for Environmental Comfort Performance of Korean Traditional Residence," Proceeings of the Second International Conference on Advances in Computing, Communication and Information Technology (CCIT 2014).

[11] E. Ahn and J. Kim, 2012, "Computational Analysis of Air Flows Inside Korean Traditional House,” Multimedia Institution, 15(3)

[12] T. Kim and S. Han , 2013, “A Composition of Monitoring System For Environmental Comfort Performance of Korean Traditional Residence", AMRESE 2014.

[13] S. Kim, K. Kim, J. Park and S. Han, 2014, "A Process of Value Assessment for Building Components of Hanok Residence," Proceeings of the Second International Conference on Advances in Computing, Communication and Information Technology (CCIT 2014).

[14] T. Kim, K. Kim, S. Han, 2015 "Implementation of Intelligent PreOccupancy Evaluation for Hanok Performance", International Conference on Advances in Agricultural, Biological \& Environmental Sciences (AABES 2015).
About Author (s):

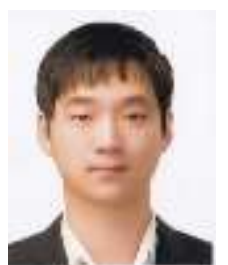

Tae-Ryong Kim

- Master's Program, School of Architecture, Chonnam National University in Korea.

- Research Interests: Architectural Design, Integrative Design, Architectural Energies and Performance Engineering

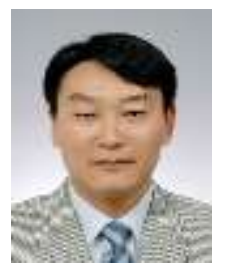

Seung-Hoon Han

- Professor, School of Architecture,

Chonnam National University in Korea.

- Research Interests: Architectural Design, Urban Planning, Building Information Modeling and Performance Engineering 